\title{
TECHNICAL EFFICIENCY AND MANAGEMENT FACTORS IN PLANTAIN PRODUCTION IN HUMID FOREST ZONE OF NIGERIA: \\ A SIMULATION ANALYSIS
}

D O Awotide and M A Y Rahji

Department of Agricultural Economics, University of Ibadan, Ibadan, Nigeria

A O Adejobi and A S Bamire

Department of Agricultural Economics, Obafemi Awolowo University, Ile-Ife, Nigeria

\section{Abstract}

The paper investigated the effect of changing some management factors on technical efficiency in plantain production with a view to understanding the functional relationship between technical efficiency and agricultural productivity. Data were collected from a cross-sectional survey of two local government areas and six villages in Ibadan area of Oyo State in the humid forest zone of Nigeria. Stochastic frontier and multiple regression models were fitted and a simulation analysis was carried out on the management levels of plantain farmers. The results revealed that educational level alone did not significantly influence technical efficiency but its combination with extension assistance significantly influenced technical efficiency in the study area. Periodic extension assistance received significantly influenced technical efficiency.

JEL Q16

Keywords: plantain, stochastic frontier, technical efficiency, management factors, simulation analysis

\section{1}

\section{Introduction}

Plantain and banana have been an important traditional staple food for both the rural and urban populace in Nigeria. They have diverse uses to millions of Nigerians serving as a source of revenue for smallholders who produce them on mixed and sole farms (Baiyeri, 1996). However, the level of production of plantain in Nigeria has been inconsistent and low (FOS, 1999) Reported yield is as low as $15 \mathrm{t} / \mathrm{ha}$ (Echibiri, 1996) as against $26 \mathrm{t} / \mathrm{ha}$ in Cameroon (Ngalani, 1996). To produce sufficient banana and plantain fruits to meet the demand associated with rising population pressure, the current level of its production must be improved. This implies that the limited resources available to plantain farmers have to be optimised. This becomes even more necessary in view of the prevailing traditional systems of production in Nigeria (Ogunfowora $\&$ Olayide, 1975). The production of plantain in Oyo State is generally affected not only by availability of land, labour, capital, and management but also by the efficiency of use of these resources. The efficient allocation of inputs will lead to the minimisation of cost, which invariably maximises profit, and motivate farmers to produce more. This leads to competitiveness in plantain production and enhance food security.

The crucial role of efficiency in increasing agricultural output has been widely recognised by researchers and policy makers (Bravo-Ureta \& Evenson, 1994; Xu \& Jeffery, 1998; Amaza \& Olayemi, 1999; Adewuyi \& Okunmadewa, 2001). Thus, considerable efforts have been devoted to the analysis of farm level efficiency in developing countries. An underlying factor behind many of the studies is that efforts designed to improve efficiency would be more 
cost-effective if farmers are making efficient use of existing technology, rather than introducing new technologies as a means of increasing agricultural output (Shapiro, 1983).

Determining the efficiency status of farmers is very important for policy purposes. Efficiency is also a very important factor of productivity growth. In an economy where technologies are lacking, efficiency studies will be able to show that it is possible to raise productivity by improving the efficiency of use of existing resources or developing new technology. It also helps to determine the under-utilisation or overutilisation of factor inputs. It is against this backdrop that this study aims to model the technical efficiency and some management factors of farmers in the production of plantain in Oyo State, Nigeria.

\section{2}

\section{Methodology}

\subsection{Study area, data collection and sampling procedure}

The study was conducted in Ibadan area of Oyo State. This area falls within the humid forest zone of Nigeria and has great potential for the cultivation of almost all types of crops. The rainy period is between April and October with an average annual rainfall of $1100 \mathrm{~mm}$, spread over an average of between $90-100$ days annually. Monthly sunshine hours fluctuate between 6.6 and 8.1 hours. Temperature ranges between 21.1 and 23.6 degrees centigrade and the maximum temperature ranges between 29.3 and 34.5 degrees centigrade. Relative humidity varies between 60 and 80 percent (IITA, 2002). This climatic condition is highly favourable to plantain production. This reflects the importance of plantain in Oyo State.

Data used for this study were collected in the 2003 plantain harvesting season through the use of well-structured questionnaires. Information on farm size, farm production, cost of inputs, prices of inputs and output, incomes and their sources, labour time allocation and utilisation and socio-economic variables such as age and education were collected. The cross-sectional survey covered two local government areas and three villages within each area. A multistage sampling procedure was employed in selecting the sample. Purposive sampling was employed to select two local government areas (LGAs) namely Ibadan Northwest and Akinyele notable for plantain production in the state. This constituted the first stage of sampling. A list of all major plantain planting villages within these two LGAs was then obtained from the State's Agricultural Development Programme (OYSADEP). From this, three villages were chosen at random from each LGA constituting the second stage of sampling. Within the identified villages, 15 plantain farmers were randomly selected at the third stage of sampling. Ninety questionnaires were administered in total out of which 15 were rejected for inconsistency and inadequate information.

\subsection{Model formulation}

Stochastic frontier production function was used to determine the technical efficiency of plantain farmers in the study area. The predicted technical efficiencies were then used in a regression analysis to obtain their respective determinants. The modelling of the factors influencing the technical efficiency are grouped into two effects viz. environment and management effects. Although studies have been conducted on technical efficiency in recent times, the inclusion of environment as a factor influencing technical efficiency has not been considered (Tadesse \& Krishnamoorthy, 1997; Wilson et al., 1998; Amaza \& Olayemi, 1999; Ajibefun \& Abdulkari, 1999; Oredipe \& Akinwunmi, 2000; Adewuyi \& Okunmadewa, 2001; Amaza et al., 2001; Ajibefun et al., 2002). In addition to this observation, the management factors employed in the studies were considered separately with no attempt made to have a combined effect and to vary these factors with a view to understanding which combination will significantly influence technical efficiency. This study attempts to bridge this gap in knowledge in the literature. A simulation analysis of efficiency measurement in plantain production is then conducted to analyse the effect of changing management levels on the technical efficiency of plantain production. 


\subsection{Stochastic frontier production function}

Following Aigner et al. (1977) and Meeusen and Van dan Broeck (1977) method of estimating a stochastic frontier production function in which the disturbance term $(\varepsilon)$ is composed of two parts, a systematic term (V) and one-sided (U) component, a Cobb-Douglas production function of the following form was specified:

$\mathrm{Q}=\mathrm{g}\left(\mathrm{X}_{\mathrm{a}} ; \beta\right)+\varepsilon_{\mathrm{j}}$

Where $\mathrm{Q}$ is the quantity of agricultural output, $X_{a}$ is vector of input quantities, and $\beta$ is a vector of parameters.

$\varepsilon_{j}=($ error term $)$ is defined as

$\varepsilon_{j}=v_{j}+u_{j} \quad \mathrm{j}=1,2, \ldots \ldots \ldots \ldots \mathrm{n}$ farms

On the assumption that $u_{j}$ and $v_{j}$ are independent, the parameters of the production frontier (Eq. 8) were estimated using maximum likelihood estimation method by an econometric software called LIMDEP Version 7.0 (Greene, 1998). The farm-specific technical efficiency $\left(\mathrm{TE}_{\mathrm{j}}\right)$ of the $\mathrm{j}^{\text {th }}$ farmer was estimated by using the expectation of $u_{i}$ conditional on the random variable $\varepsilon_{j}$ as shown by Battesse and Coelli (1988). That is,

$\mathrm{TE}_{\mathrm{j}}=\exp \left(-\mathrm{u}_{\mathrm{j}}\right)$

So that $0 \leq \mathrm{TE}_{\mathrm{j}} \leq 1$

The estimating equation is

$\operatorname{InQ}=\beta_{0}+\beta_{1} \operatorname{In} X_{i}+\beta_{2} \operatorname{In} X_{i}+\beta_{3} \operatorname{InX}+\left(v_{i}-u_{1}\right)(4)$

Where

$\mathrm{Q}=$ output of plantain $(\mathrm{kg}$ per harvesting season);

$\mathrm{X}_{1}=$ value of materials including expenditures on suckers, and other purchased inputs used for the production of plantain (N) ${ }^{1}$;

$\mathrm{X}_{2}=$ family and hired labour used in plantain production (hours);

$\mathrm{X}_{3}=$ the area devoted to plantain production (ha);

$\beta_{i}=$ parameters to be estimated $(\mathrm{i}=0,1,2$, 3)

$\mathrm{v}=$ is the two-sided, normally distributed random error.

$\mathrm{u}=$ is the one-sided efficiency component with a half-normal distribution.
${ }^{1}$ As at December 2004, 1 US\$ equals 132.5 $(\mathrm{N}=$ Naira $)$.

\subsection{Multiple regression model}

To model the technical efficiency effects, a regression model was fitted to the dataset.

$\mathrm{V}_{\mathrm{i}}^{*} \quad=\beta \mathrm{Z}_{\mathrm{i}}+\mathrm{E}_{\mathrm{i}}$

$\mathrm{i} \quad=1,2, \ldots \ldots \ldots \ldots \ldots . . \mathrm{n}$ farm

Where,

$\mathrm{V}_{\mathrm{i}}{ }^{*}=$ Technical efficiency level

$\mathrm{Z}_{\mathrm{i}}=$ Technical efficiency effects

$\beta=$ Vector of unknown parameters

$\mathrm{E}_{\mathrm{i}}=$ Independently distributed error term.

The explanatory variables include:

$\mathrm{Z}_{1}=$ Environment effect (e.g. soil fertility, rainfall, and soil erosion)

$\mathrm{Z}_{2}=$ Management effect (i.e. educational level, access to extension services and work force)

\subsection{Environment}

Environmental factors include rainfall, soil type, humidity, temperature, erosion and vegetation. These factors are location specific. In most socio-economic surveys, these factors are represented by ordinal scales such as good/ bad, high/medium/low, etc. (Lomperis, 1991; Yanaihara, 1993; Flaherty \& Jenglalern, 1995). For more meaningful modelling, Odulaja and Kiros (1996) transformed these to continuous scales using the uniform-rank transform method. This is performed by ranking the data for each variable in ascending order and then dividing by the total sample size. The mean of the uniform-ranks over all the environmental variables is then obtained for each sample to represent the environmental index. Hence, the environmental index, E, is distributed in the interval $[0,1]$. In the study, soil fertility level, rainfall condition and gravity of erosion constituted the environment effect.

\subsection{Management}

Various factors that describe management include both physical properties and personal qualities possessed by the farmers. These include number of work implements, work 
force, literacy level, and external assistance on production. Uniform-rank transform method was also used to obtain the management index (M) since many of them are measured on ordinal scales. In the study, educational level, access to extension services and work force constituted the management effect.

\subsection{Simulation analysis}

To investigate the effect of changing the management level on technical efficiency, a simulation analysis was carried out.

\subsection{Results and discussion}

Summary statistics of some important socioeconomic variables are presented in Table 1.
The mean age of 52 years shows that the farmers are relatively old based on the average life span of 49 years for Nigeria (WHO, 1991), with a relatively small range in age $(\mathrm{CV} \%=22 \%)$. This could have serious implication on the future of plantain cultivation in the study area. The literacy level is low among the sampled farmers with an average of four years of formal education and a high variation between farmers. This could affect their choice of inputs, the utilisation of existing inputs, and their willingness to adopt improved technologies. Mean income made by plantain farmers was N61272.18/ha per harvesting season. This is high when compared to mean income of N51976.74/ha made by rice farmers in Ogun State (Awotide, 2004).

Table 1

Summary statistics of some socio-economic variables of the respondents

\begin{tabular}{|l|c|c|c|}
\hline \multicolumn{1}{|c|}{ Variable } & $\begin{array}{c}\text { Mean } \\
\text { deviation }\end{array}$ & $\begin{array}{c}\text { Standard } \\
\text { Variation \% }\end{array}$ & Coefficient of \\
\hline Education (years) & 4.15 & 0.0404 & 97 \\
\hline Experience in plantain production (years) & 10.24 & 0.0620 & 22 \\
\hline Age (years) & 51.87 & 0.1141 & 57 \\
\hline Farm size (ha) & 1.348 & 0.0077 & 41 \\
\hline Income ( $)$ & 61272.18 & 100.49 & 203 \\
\hline
\end{tabular}

Source: Field data 2003

\subsubsection{Technical efficiency estimates: results from half-normal model}

The maximum likelihood (ML) estimates of the Cobb-Douglas stochastic production model are presented in Table 2. From the ML estimates for the production frontier, the coefficient of land $(0.276)$ is statistically significant. The estimate of $\lambda(1.69)$ and $\sigma(0.64)$ are large and significantly different from zero at 1 per cent. These indicate a good fit and the correctness of the specified distribution assumptions for the decomposed error term. 


\section{Table 2}

Stochastic production frontier for plantain in the study area

\begin{tabular}{|l|c|c|}
\hline \multicolumn{1}{|c|}{ Variable } & \multicolumn{2}{c|}{ Stochastic Frontier } \\
\cline { 2 - 3 } & Parameters & t-values \\
\hline Constant & $\begin{array}{c}3.194 \\
(0.402)\end{array}$ & $7.951^{* * *}$ \\
\hline Materials $(\mathrm{K})$ & $\begin{array}{c}0.063 \\
(0.111)\end{array}$ & 0.565 \\
\hline Land $(\mathrm{R})$ & 0.276 & $3.217^{* * *}$ \\
& $(0.086)$ & $2.417^{* *}$ \\
\hline Labour $(\mathrm{L})$ & 0.364 & $2.101^{* *}$ \\
& $(0.150)$ & $10.141^{* * *}$ \\
\hline Lambda $\lambda$ & 1.691 & \\
\hline Sigma $\sigma \quad * * *$ Significant at $1 \%$ & $(0.805)$ & \\
\hline Log likelihood & $\begin{array}{c}0.64 \\
(0.063)\end{array}$ & Source: Field data 2003 \\
\hline
\end{tabular}

The numbers in parenthesis are standard error

\subsubsection{Returns to scale}

There is evidence of decreasing returns to scale for the underlying technology as the elasticity of the production function with respect to the factors of production is less than one $\left(\Sigma b_{1}=\right.$ $0.063+0.276+0.364=0.703)$. This implies that the farmers are in stage II in the production function curve. At this stage, every addition to the production inputs would lead to less than proportionate addition to the output. This suggests that it pays the farmers to continue to operate at this stage.

\subsection{Technical efficiency}

The frequency distribution of the predicted technical efficiency of the farmers is presented in Table 3. The mean technical efficiency for the sample is 66.3 per cent, with a clustering in the 51 to 90 per cent efficiency range. There is gap of 33.7 per cent to get to the frontier. The implication of this is that plantain farmers can increase their output using the existing resources.

Table 3

Frequency distribution of the predicted technical efficiency of plantain farmers

\begin{tabular}{|c|c|c|c|}
\hline Efficiency levels & Frequency & Percentage & Cumulative \\
\hline $10-20$ & 2 & 2.67 & 2.67 \\
\hline $21-30$ & 4 & 5.33 & 8.00 \\
\hline $31-40$ & 5 & 6.67 & 14.67 \\
\hline $41-50$ & 8 & 10.66 & 25.33 \\
\hline $51-60$ & 9 & 12.00 & 37.33 \\
\hline $61-70$ & 9 & 12.00 & 49.33 \\
\hline $71-80$ & 15 & 20.00 & 69.33 \\
\hline $81-90$ & 14 & 18.67 & 88.00 \\
\hline$>90$ & 9 & 12.00 & 100.0 \\
\hline Total & 75 & 100.0 & \\
\hline
\end{tabular}




\subsection{Simulation analysis results}

Out of the two effects, management level of farmers is probably the most controllable of the two independent variables in the multiple regression model. It is against this backdrop that management effect was used in the simulation analysis. This was carried out by varying the management levels, $\mathrm{M}$, within interval $[0,1]$. Simulation results show how changes in these factors and their combination would affect technical efficiency (Table 4). In this simulation analysis, educational level and extension assistance were used because they could easily be classified and varied. Table 4 shows that the environmental index is not significant in all the management levels. The results of the management index are of great interest. The management index in all the management levels carries the expected positive sign except in M8. The results reveal that farmers' educational level alone will not significantly influence technical efficiency. But extension assistance received once in three months and once in a month will significantly influence technical efficiency. The combination of educational level and extension assistance will significantly affect the technical efficiency of plantain production in the study area. Note that this applies with the assumption that workforce (the third variable in the management effect) remains constant.

\section{Table 4}

Multiple regression results and changes in management levels given changes in some management factors

\begin{tabular}{|c|c|c|c|c|c|c|}
\hline Variable & $\begin{array}{c}\text { Management } \\
\text { level }\end{array}$ & $\begin{array}{l}\text { Mean } \\
\text { value }\end{array}$ & $\begin{array}{c}\text { Increase in } \\
\text { Management } \\
\text { level }\end{array}$ & Constant & $\begin{array}{c}\text { Environ- } \\
\text { mental } \\
\text { index }\end{array}$ & $\begin{array}{c}\text { Management } \\
\text { index }\end{array}$ \\
\hline $\begin{array}{l}\text { Normal } \\
\text { (as obtained } \\
\text { from data) }\end{array}$ & M & 0.644 & - & $\begin{array}{c}0.438 \\
(1.95)^{*}\end{array}$ & $\begin{array}{l}-0.0066 \\
(-0.030)\end{array}$ & $\begin{array}{c}0.357 \\
(1.433)\end{array}$ \\
\hline Ed. level (=6) & M1 & 0.667 & 0.023 & $\begin{array}{c}0.501 \\
(2.101)^{* *}\end{array}$ & $\begin{array}{l}0.0091 \\
(0.41)\end{array}$ & $\begin{array}{c}0.233 \\
(0.896)\end{array}$ \\
\hline $\begin{array}{l}\text { Ed. level } \\
(7-12)\end{array}$ & M2 & 0.744 & 0.100 & $\begin{array}{c}0.483 \\
(1.949)^{*}\end{array}$ & $\begin{array}{l}0.0091 \\
(0.41)\end{array}$ & $\begin{array}{c}0.233 \\
(0.896)\end{array}$ \\
\hline $\begin{array}{l}\text { Ed. level } \\
(>12)\end{array}$ & M3 & 0.821 & 0.177 & $\begin{array}{c}0.465 \\
(1.735)^{*}\end{array}$ & $\begin{array}{r}0.0091 \\
(0.041)\end{array}$ & $\begin{array}{c}0.233 \\
(0.896)\end{array}$ \\
\hline Ext. asst. (4) & M4 & 0.681 & 0.037 & $\begin{array}{c}0.235 \\
(0.921)\end{array}$ & $\begin{array}{c}0.016 \\
(0.073)\end{array}$ & $\begin{array}{l}0.611 \\
(2.137)^{* *}\end{array}$ \\
\hline Ext. asst. (5) & M5 & 0.758 & 0.114 & $\begin{array}{c}0.188 \\
(0.690)\end{array}$ & $\begin{array}{c}0.016 \\
(0.073)\end{array}$ & $\begin{array}{l}0.611 \\
(2.137)^{* *}\end{array}$ \\
\hline $\begin{array}{l}\text { Ed. Level (6) } \\
\text { and Ext. asst. } \\
(4)\end{array}$ & M6 & 0.704 & 0.060 & $\begin{array}{c}0.015 \\
(0.04)\end{array}$ & $\begin{array}{c}0.047 \\
(0.217)\end{array}$ & $\begin{array}{l}0.890 \\
(2.144)^{* *}\end{array}$ \\
\hline $\begin{array}{l}\text { Ed. level (7-12) } \\
\text { and Ext. asst. } \\
\text { (4) }\end{array}$ & M7 & 0.781 & 0.137 & $\begin{array}{c}-0.067 \\
(-0.179)\end{array}$ & $\begin{array}{c}0.0474 \\
(0.222)\end{array}$ & $\begin{array}{l}0.890 \\
(2.144)^{* *}\end{array}$ \\
\hline $\begin{array}{l}\text { Ed. level } \\
(>12) \text { and } \\
\text { Ext. asst. (4) }\end{array}$ & M8 & 0.857 & 0.213 & $\begin{array}{l}2.019 \\
(2.659)^{* * *}\end{array}$ & $\begin{array}{c}-0.109 \\
(-0.265)\end{array}$ & $\begin{array}{l}-1.694 \\
(-2.163)^{* *}\end{array}$ \\
\hline $\begin{array}{l}\text { Ed. level }(=6) \\
\text { and Ext. asst. } \\
\text { (5) }\end{array}$ & M9 & 0.781 & 0.137 & $\begin{array}{c}-0.067 \\
(-0.179)\end{array}$ & $\begin{array}{c}0.047 \\
(0.217)\end{array}$ & $\begin{array}{l}0.890 \\
(2.144)^{* *}\end{array}$ \\
\hline
\end{tabular}




\begin{tabular}{|l|c|c|c|c|c|c|}
\hline $\begin{array}{l}\text { Ed. level } \\
\text { (7-12) and }\end{array}$ & M10 & 0.857 & 0.213 & $\begin{array}{c}-0.135 \\
(-0.336)\end{array}$ & $\begin{array}{c}0.0474 \\
(0.217)\end{array}$ & $\begin{array}{c}0.890 \\
(2.144)^{* *}\end{array}$ \\
\hline $\begin{array}{l}\text { Ext. asst. (5) } \\
\begin{array}{l}\text { Ed. level (>12) } \\
\text { and Ext. asst. } \\
\text { (5) }\end{array}\end{array}$ & M11 & 0.934 & 0.290 & $\begin{array}{c}-0.204 \\
(-0.472)\end{array}$ & $\begin{array}{c}0.0474 \\
(0.217)\end{array}$ & $\begin{array}{c}0.890 \\
(2.144)^{* *}\end{array}$ \\
\hline
\end{tabular}

The figures in parenthesis are t-values

Source: Computed from field data 2003

***Significant at $1 \% \quad * *$ Significant at $5 \% \quad{ }^{*}$ Significant at $10 \%$

Ed. refers to the years of formal education and Ext. asst. refers to the frequency of which farmers receive extension agents: $(4)=$ once in three months and $(5)=$ once in a month.

\section{3}

\section{Conclusion}

The investigations reported in this paper show the sensitivity of technical efficiency to management factors. Given the production resources at their disposal, and the output levels, plantain farmers in the study area are fairly efficient in the use of their resources. Management effect was found to be significant at higher management levels. This implies that management effect has a significant influence on the technical efficiency of plantain farmers. From the simulation analysis, it could be concluded that if the variables describing management effect were improved upon, either separately or in combination, the management level would increase with consequential increase in technical efficiency of plantain farmers. This has positive implication on selfsufficiency in plantain production and ensuring food security for farm household in the study area and in Nigeria as a whole. Improving the management level cannot be achieved without additional cost; therefore, it is recommended that policies that would help farmers to improve on their management level at a reduced cost would go a long way to sustain plantain production in the study area.

\section{References}

1 ADEWUYI, S.A. \& OKUNMADEWA, F.Y. (2001) "Economic efficiency of crop farmers in Kwara State, Nigeria”, Nigerian Agricultural Development Studies, 2(1): 45-57.

2 AIGNER, D.J; LOVELL, C.A.K. \& SCHMIDT, P.J. (1977) "Formulation and estimation of stochastic frontier production function models", J. Econometrics, 6: 21-37.

3 AJIBEFUN, I.A.; BATTESE, G.E. \& DARAMOLA, A.G. (2002) "Determinants of technical efficiency in smallholder food crop farming: application of stochastic frontier production function", Quarterly Journal of International Agriculture, 41(3): 225-240.

4 AJIBEFUN, I. \& ABDULKADRI, O.A. (1999) "An investigation of technical inefficiency of production of farmers under the National Directorate of Employment in Ondo State, Nigeria", Applied Economics Letter, Routledge, 6: 111-114.

5 AMAZA, P. \& OLAYEMI, J.K. (1999) "An investigation of production efficiency in food crop enterprises Gombe State, Nigeria”, Journal of Rural Economics and Development, 13(2): 111-122.

6 AMAZA, P.S.; ONU, J.I. \& OKUNMADEWA, F.Y. (2002) "Identification of factors that influence the technical efficiency of cotton farmers in Nigeria", Nigerian Agricultural Development Studies, 2(1): 133-145.

7 AWOTIDE, D.O. (2004) Resource use efficiency and inputs substitution in upland rice production in Ogun State, Nigeria, Unpublished Ph.D. thesis, Department of Agricultural Economics, University of Ibadan.

8 BAIYERI, K.P. (1996) Characterisation, correlation, path analysis and selection indices of Musa genotypes under different environment, A Ph.D. Research Proposal, Department of Crop Science, University of Nigeria, Nsukka: 1-8. 
9 BATTESSE, G.E. \& COELLI, T.J. (1988) "Prediction of firm level technical efficiencies with a generalised frontier production function and panel data" Econometrics, 38: 387-399.

10 BRAVO-URETA, B.E \& EVENSON, R.E. (1994) "Efficiency in agricultural production. The case of peasant farmers in eastern Paraguay", Agric. Econ, 10: 27-37.

11 ECHIBIRI, T.O. (1996) "Plantain and banana production in Imo State”, pp. 61-62. In Plantain and Banana: Production and Research in West and Central Africa, (R. Ortiz \& M.O. Akoroda, eds.), Proceedings of a regional workshop held at High Rainfall Station, Onne, Rivers State, Nigeria. IITA, Ibadan, Nigeria.

12 FLAHERTY, M. \& JENGLALERN, A. (1995) "Defferences in assessments of forest adequacy among women in northern Thailand", J. Dev. Areas, 29: 237-254.

13 FOS. (1999) Annual Abstract of Statistics, Federal Office of Statistic (FOS), Nigeria, 1999 Edition: 323.

14 GREENE, R.W. (1998) LIMDEP Version 7.0 User's manuals, Bellport. N.Y. Econometric software, 1998.

15 INTERNATIONAL INSTITUTE OF TROPICAL AGRICULTURE (IITA). (2002) Several issues of the weekly bulleting published by the Publications unit of the institute, IITA, Ibadan.

16 LOMPERIS, A.M.T. (1991) "Teaching mothers to read: Evidence from Colombia on the key role of maternal education in pre-school child nutrition health", J. Dev. Areas, 26: 25-52.

17 MEEUSEN, W. \& VAN DEN BROECK, J. (1977) "Efficiency estimation from CobbDouglas production functions with composed error", Int. Econ, Rev., 18: 435-444.

18 NGALANI, J.A. (1996) "Country report from Cameroon”, pp. 81-82, In Plantain and Banana: Production and Research in West and Central Africa (R. Ortiz and M.O. Akoroda, eds.), Proceedings of a regional workshop held at High Rainfall Station, Onne, Rivers State, Nigeria. IITA, Ibadan, Nigeria.
19 ODULAJA, A. \& KIROS, F.G. (1996)

"Modelling agricultural production of small-scale farmers in sub-Saharan Africa: A case study in western Kenya”, Agricultural Economics, 14: 8591.

20 OGUNFOWORA, O. \& OLAYIDE, S.O. (1975) "Resource problems of rural economy", In Element of Rural Economics, Ibadan University Press, Ibadan: 191-217.

21 OREDIPE, A.A. \& AKINWUNMI, J.A. (2000) "Resource productivity and efficiency among farmers adopting improved maize technology in Ogun State", Nigerian Agricultural Development Studies, 1(2): 27-38.

22 SCHULTZ, T.W. (1956) "Reflections of agricultural production, output and supply", Journal of Farm Economics, 38(3): 748-762.

23 SHAPIRO, K.H. (1983) "Efficiency differentiates in peasant agriculture and their application of development policies", J.Dev.Stud, 19: 179-190.

24 SHIELDS, M.L.; RANNIYAR, G.P. \& GOODE, F.M. (1993) "A longitudinal analysis of the factors influencing increased technology adoption in Swaziland, 1985 - 1991", J. Dev. Areas, 27: 469-484.

25 TADESSE, B. \& KRISHNAMOORTHY, S. (1997) "Technical efficiency in paddy farms of Tamil Nadu: an analysis based on farm size and ecological zone", Agric. Econs, 16: 185-192.

26 WHO. (1991) World Health Organisation, News Reports, 1991.

27 WILSON, P.; HADLEY, D. RAMSDEN, S. \& KALTSAS, I. (1998) "Measuring and explaining technical efficiency in UK potato production", Journal of Agricultural Economics, 49(3): 294305.

28 XU, X. \& JEFFREY, S.R. (1998) "Efficiency and technical progress in traditional and modern agriculture: evidence from rice production in China”, Agric. Econs, 18: 157-165.

29 YANAIHARA, K. (1993) "Economic ties between workers and their agricultural homeland in Nigeria and Zambia”, Afr. Study Monogr., 14: 169-187. 